\title{
RANDOM REGRESSION ANIMAL MODELS FOR GENETIC EVALUATION OF TEST-DAY MILK YIELD AND MILKING DURATION IN HOLSTEIN FRIESIAN
}

\author{
A.A. Amin \\ Department of Animal Production, Faculty of Agriculture, University of Suez \\ Canal, 41522- Ismailia, Egypt
}

\section{SUMMARY}

Random regression animal model was applied for analyzing the relationships between daily milk yield (MK) and milking duration (DR). The current analyzed data involved 103563 sample test-day records from multiparous Hungarian HolsteinFriesian cows. A cubic random regression was applied for representing additive genetic variances in all studied traits across all different days in milk (12 groups). Based on multi-lactation random regression data-set analysis, the role of inheritance was greatest during the later stages of lactation. Estimates of $h^{2}{ }_{M K}$ ranged from 0.17 to 0.54. While estimates of $h_{D R}^{2}$ were very low during the first 60 days of lactation, being not more than 0.04. During the $2^{\text {nd }}$ half of lactation the estimates ranged from 0.35 to 0.39. Results of genetic variations for lactation records during early production life showed that highest milk harvest with intermediate milking rate could be achieved. Estimates of expected breeding values for milk yield and milking duration increased in different rates with progressing days in milk groups. These results may indicate that individual selection results would be favorably achieved during the late part of lactation. Additive genetic correlations between measures of all traits at different lactation months continuously decreased as the interval between test days increased. Additive genetic correlations between milking duration and milk yield were positive and considerably high. Correlations between expected breeding values of both traits ranged from 0.41 to 0.83 (mean $=0.69$ ) across different lactation months. More details on estimates of breeding values, estimates of permanent environmental and additive genetic correlations for all traits were tabulated.

Keywords: Milk yield, milking duration, random regression, permanent environmental

\section{INTRODUCTION}

Milking duration is among the most important functional traits in dairy cattle. It is well known in practice that long milking cows are not desirable. Therefore, genetic selection against this characteristic would be appreciated by farmers. Milking time for cows producing 9 to $11 \mathrm{~kg}$ of milk should not exceed 4.25 minutes, with an additional $3 / 4$ minute for each additional $4.5 \mathrm{~kg}$ of milk harvested (Matthew, 2001). Most of milking characteristics can be measured as a threshold traits classifying cows into categories, or alternatively recording duration in time quantitatively for each cow during routine test day. Different approaches are described by Banos and Burnside (1992). Zwald et al. (2005) found that average milking duration for a single milking

Issued by The Egyptian Society of Animal Production 
was $4.5 \mathrm{~min}$. Estimated heritability of milking duration was 0.17 and predicted transmitting abilities of individual sires ranged from $-0.48 \mathrm{~min}$ for sires with the short time milking daughters to 0.59 min for sires with the long time milking daughters.

A recent approach has been to use Covariance Functions (CF, Kirkpatrick and Heckman, 1989) and Random Regression models (RR Henderson, 1982; Schaeffer and Dekkers, 1994). The equivalence of CF and RR has been described by many authors (e.g. Meyer and Hill, 1997; van der Werf et al., 1998). In this framework, infinite-dimensional stochastic models have been proposed with the phenotype represented as a continuous function of time. Advantages of random regression testday models over those analyzing 305-day lactation yields are now widely acknowledged. The approach of test-day (TD) yields can account more precisely for environmental factors that could affect cows differently during lactation. Random regressions allow for a different shape of lactation curves. The RR model also allows a cow to be evaluated on the basis of any number of TD records during lactation and it can account for different genetic, permanent environmental and residual variances in the course of lactation. The work of Jamrozik and Schaeffer (1997) was an early published study on using RR for describing genetic effects. Further developments of the variance component estimation by RR model were suggested in several recent studies.

The objectives of the current study were to estimate (co)variance components of the first three lactations data with random regression models and to characterize some genetic aspects of test-day milk yield and milking duration across lactation in Hungarian Holstein-Friesian.

\section{MATERIALS AND METHODS}

Data consisted of 103563 test day records (TDR) on daily milk yield $\left(\mathrm{Mk}_{\mathrm{Kg} / \mathrm{day}}\right)$, and milking duration $\left(\mathrm{DR}_{\min }\right)$. The current data set involved the $1^{\text {st }}$, the $2^{\text {nd }}$ and $\geq$ the $3^{\text {rd }}$ lactation of Hungarian Holstein Friesian provided by Hungarian Holstein Association. All studied traits were recorded on each test day between 5 and 365 days in milk (DIM). Cows had to have at least two lactations, while the average was 3.7 lactations with 7.16 test-day records. Data were recoded on cows calving between 1996 and 2000. Number of TDR per lactation was not less than five observations. Days in milk (DIM) were classified into 12 monthly groups with 30 days interval. Structure of the current data set is given in Table 1.

Table 1. Structure of the data and simple statistics generated from raw data of milkability traits

\begin{tabular}{|c|c|c|c|c|c|c|c|c|}
\hline \multicolumn{3}{|c|}{ Simple Statistics } & \multicolumn{6}{|c|}{ Data Structure } \\
\hline & $\mathrm{Mk}_{\mathrm{Kg}}$ & $\mathbf{D r} \mathbf{r}_{\min }$ & & $\mathbf{P r}^{1}$ & $\mathbf{P r}^{2}$ & $\mathbf{P r}^{3}$ & $\operatorname{Pr}^{4}$ & $\operatorname{Pr}^{5}$ \\
\hline Mean & $24.67(8.2)^{S D}$ & $4.88(1.4)$ & Cows & 4173 & 3012 & 2660 & 2071 & 1843 \\
\hline CV & 33.21 & 46.7 & TDR & 39226 & 24397 & 19152 & 13047 & 7741 \\
\hline Ph-R & 4.40 to 43.70 & 1.17 to 24.20 & Sires & 453 & 316 & 196 & 174 & 153 \\
\hline Sd-R & -2.47 to 2.32 & -1.27 to 15.84 & Dams & 3967 & 2784 & 2163 & 1754 & 1843 \\
\hline $\mathbf{b}_{\text {DrMk }}$ & \multirow{2}{*}{\multicolumn{2}{|c|}{$\begin{array}{l}0.139 \pm 0.001_{\min / \mathrm{Kg}} \\
1.405 \pm 0.036_{\mathrm{min} / \mathrm{Kg}}\end{array}$}} & $\mathbf{b}_{\text {DrMk }}$ & 0.144 & 0.159 & 0.146 & 0.139 & 0.125 \\
\hline $\mathbf{a}$ & & & $\mathbf{a}$ & 1.624 & 1.088 & 1.094 & 1.133 & 1.204 \\
\hline $\mathbf{R}_{\text {DrMk }}$ & \multicolumn{2}{|c|}{$0.7 \overline{2} 4 \pm 0.001$} & $\mathbf{R}_{\text {DrMk }}$ & 0.648 & 0.792 & 0.799 & 0.789 & 0.794 \\
\hline
\end{tabular}




\section{Statistical analysis}

Random regression (RR) models have been suggested for genetic analysis of test day (TD) yields by Schaeffer and Dekkers (1994) because of their ability to model a separate lactation curve for every animal. Single trait RR models were applied to first lactation milk, fat and protein of test-day yield data with different functions for fixed and random regressions (Jamrozik and Schaeffer, 1997 and Jamrozik et al., 1998). In the simulation study of Strabel and Misztal (1999), RR models were significantly better than an analysis of $305 \mathrm{~d}$ in terms of correlation between estimated and true breeding values.

The random regression model used in the study was

$$
Y_{i j k l m}=H T D_{i l}+\sum_{n=1}^{n_{p}} \beta_{i l o} \chi_{k l m o}+\sum_{n=1}^{n_{p}} \alpha_{k l o} \chi_{k l m o}+\sum_{n=1}^{n_{p}} \psi_{k l o} \chi_{k l m o}+\varepsilon_{i j k l m}
$$

Where:- $Y_{i j k l m}$ is the $m^{\text {th }}$ test day observation of $k^{\text {th }}$ cow in $l^{\text {th }}$ lactation, $H T D_{i l}$ is the independent fixed effect of $i^{\text {th }}$ herd-test-date for $l^{\text {th }}$ lactation, $\alpha_{k l o}$ is the $O^{\text {th }}$ random regression coefficient of additive genetic effect of $k^{\text {th }}$ cow in $l^{\text {th }}$ lactation on DIM, $\psi_{k l o}$ is the $o^{\text {th }}$ random regression coefficient of permanent environmental effect of $k^{\text {th }}$ cow in $l^{\text {th }}$ lactation on DIM, $n_{p}$ is the number of parameters fitted in days in milk function, $\beta_{j l o}$ is the $o^{\text {th }}$ fixed regression coefficient of $j^{\text {th }}$ DIM of $l^{\text {th }}$ lactation, $X_{k l m o}$ is the $o^{\text {th }}$ dependent trait on DIM, and $\varepsilon_{i j k l m}$ is the random residual.

The following (co)variance structure was assumed:

$$
V\left[\begin{array}{c}
\alpha \\
\psi \\
\varepsilon
\end{array}\right]=\left[\begin{array}{ccc}
G \otimes A & 0 & 0 \\
0 & P \otimes I & 0 \\
0 & 0 & E \otimes I
\end{array}\right]
$$

where: $\mathbf{G}=$ genetic covariance matrix between random regression coefficients and traits, $\mathbf{A}=$ additive numerator relationship matrix, $\mathbf{I}=$ identity matrix, $\mathbf{P}=$ permanent environmental covariance matrix among random regression coefficients and traits, and $\mathbf{E}=$ residual variance for lactation and assumed to be constant throughout the lactation due to program limitations. Variance-covariance parameters for each of the current longitudinal traits (daily milk yield and milking duration) were estimated using the software package, DFREML (Meyer, 1998 Version 3ß). Random regression model was used with cubic as the order of polynomial fit that achieved the highest correlations between random regression coefficients. Cubic random regression was mostly used in several pervious research works. Permanent environmental effect was presented as a ration between permanent environmental variance to total phonotypic variance.

\section{RESULTS AND DISCUSSION}

\section{Multi-lactation heritability estimates using random regression model}

Results of random regression animal model were used for analyzing the relationship between investigated traits in the present study (Table 2). Heritabilty of daily milk yield $\left(\mathrm{h}^{2}{ }_{\mathrm{MK}}\right)$ ranged from 0.15 to $0.54($ mean $=0.34 \pm 0.04)$. Estimates of $\mathrm{h}^{2}{ }_{\mathrm{MK}}$ increased linearly from the $2^{\text {nd }}$ DIM group till end lactation. Estimates of $\mathrm{h}^{2}{ }_{\mathrm{MK}}$ across different DIM groups were moderately high during the last few evaluated lactation months $(>0.40)$. Druet et al. (2003) found the heritability for daily milk 
yield ranged from 0.16 to 0.39 using a random regression test day model from field data. Heritability estimates of the first lactation milk yield for particular days in milk resulting from random regression models ranged between 0.14 to 0.19 (Strabel and Misztal, 1999) and from 0.31 to 0.51 (Olori et al., 1999). Zavadilová et al. (2005) found that genetic variances were high at the beginning and end of lactation. The flattest shapes were observed during early production while the rapid increase of genetic variance occurred at the end of lactations.

Table 2. Heritabilities $\left(h^{2}\right)$, permanent-environmental effect $\left(P_{E}\right)$, additive $\left(\sigma_{A}^{2}\right)$ and phenotypic $\left(\sigma_{P}^{2}\right)$ variance components for daily milk yield (MK) and milking duration (DR) across 12 days in milk groups (DIM) using random regression animal model

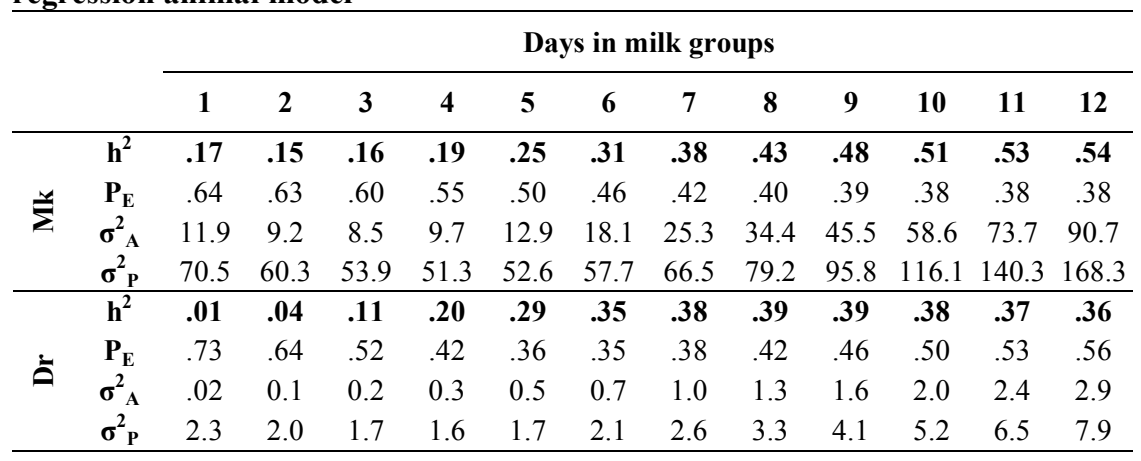

$P_{E}=\frac{\sigma_{C}^{2}}{\sigma_{P}^{2}}, \sigma_{C}^{2}:$ is the permanent environmental variance

Variations in milk yield due permanent environmental conditions were reduced with progressing days in milk (Table 2). Variations in milk yield due to permanent environmental effect were high (not less than 50\%) within early months of lactation. Whereas the corresponding estimates of additive variances were slightly low among the first four groups of DIM. Phenotypic variance of daily milk yield increased markedly after the $7^{\text {th }}$ DIM group showing high variation with advancing lactation months.

Estimates of $\mathrm{h}_{\text {DR }}^{2}$ (Table 2) were very low during early lactation months (from 0.01 to 0.11 ) and were intermediate across the $2^{\text {nd }}$ half of lactation (from 0.35 to 0.39). Heritability estimate for milking duration was low during the first half of lactation while it increased during the beginning of the $2^{\text {nd }}$ half of lactation. Zwald et al. (2005) found that low heritability estimates for milking time may be due to the wideness of the interval between positive and negative predicted transmitting ability or breeding values that associated with increase estimates of permanent environmental effect. Moore et al. (1983) found that estimated heritability of the "2min milk" was 0.23 , which was significantly higher than the corresponding estimate of 0.13 for milking duration.

Estimates of permanent environmental effect (as the ratio between permanent environmental variance and phenotypic variance) $\left(\mathrm{P}_{\mathrm{E}_{\mathrm{DR}}}\right)$ for milking duration were high during both ends of lactation ranging from 0.52 to 0.73 and from 0.50 to 0.56 
during the first and the last three months of lactation, respectively. On the other hand, $\mathrm{P}_{\mathrm{E}_{\mathrm{DR}}}$ decreased greatly at the middle of lactation arriving to 0.35 during the $6^{\text {th }}$ month of lactation. It appears that environmental conditions had a great contribution in variations of milking duration among different months of lactation.

\section{Estimates of heritability and permanent environmental effect within parities:}

Estimate of random regression heritabilities and permanent environmental effects for milk yield and milking duration within parities across DIM groups are presented in Tables 3. Estimates of $h^{2}{ }_{M K}$ within $1^{\text {st }}$ and $2^{\text {nd }}$ parities were higher than within others. Estimates of $\mathrm{h}^{2}$ MK within the $1^{\text {st }}$ parity ranged from 0.24 to 0.36 across lactation months except DIM ${ }^{1,2}$ and the highest values were obtained during the midlactation $\left(\mathrm{DIM}^{5,6}\right)$. Most $\mathrm{h}_{\mathrm{MK}}^{2}$ estimates were high in the $2^{\text {nd }}$ parity arriving to 0.48 with small variations among estimates across lactation. On the other hand, estimates for $\mathrm{h}_{\text {MK }}^{2}$ were low within later parities. Some authors reported great variability with high heritabilities at the beginning and at the end of lactation (Jamrozik and Schaeffer, 1997; Olori et al., 1999; and Kettunen et al., 2000). Other authors found the highest heritabilities in mid-lactation (Swalve, 1995; Rekaya et al., 1999; Liu et al., 2000; Pool and Meuwissen, 2000; Jakobsen et al., 2002; Druet et al., 2003). Zavadilová et al. (2005) reported that additive genetic variances using random regression increased with parity and heritability estimates increased in turn, especially from the $2^{\text {nd }}$ to the $3^{\text {rd }}$ lactation. The present results indicate the importance of genetic evaluation of populations within parity.

Table 3. Heritability $\left(h^{2}\right)$ estimates and permanent environmental effect $\left(P_{E}\right)$ for studied traits within the $1^{\text {st }}, 2^{\text {nd }}$, and $\geq 3^{\text {rd }}$ parity.

\begin{tabular}{|c|c|c|c|c|c|c|c|c|c|c|c|c|}
\hline \multirow{3}{*}{ DIM } & \multicolumn{6}{|c|}{ Daily Milk Yield } & \multicolumn{6}{|c|}{ Milking Duration } \\
\hline & \multicolumn{2}{|c|}{$\mathbf{P r}^{1}$} & \multicolumn{2}{|c|}{$\mathbf{P r}^{2}$} & \multicolumn{2}{|c|}{$\geq \mathbf{P r}^{3}$} & \multicolumn{2}{|c|}{$\operatorname{Pr}^{1}$} & \multicolumn{2}{|c|}{$\mathbf{P r}^{2}$} & \multicolumn{2}{|c|}{$\geq \mathbf{P r}^{3}$} \\
\hline & $\mathbf{h}^{2}$ & $\mathbf{P}_{\mathbf{E}}$ & $\mathbf{h}^{2}$ & $\mathbf{P}_{\mathbf{E}}$ & $h^{2}$ & $\mathbf{P}_{\mathbf{E}}$ & $\mathbf{h}^{2}$ & $\mathbf{P}_{\mathbf{E}}$ & $\mathbf{h}^{2}$ & $\overline{\mathbf{P}_{\mathbf{E}}}$ & $\mathrm{h}^{2}$ & $\mathbf{P}_{\mathbf{E}}$ \\
\hline 1 & .03 & .81 & .47 & .05 & .06 & .68 & .21 & .42 & .17 & .17 & .03 & .51 \\
\hline 2 & .12 & .58 & .48 & .02 & .04 & .64 & .18 & .45 & .05 & .17 & .04 & .34 \\
\hline 3 & .24 & .35 & .48 & .00 & .04 & .65 & .13 & .53 & .03 & .38 & .08 & .28 \\
\hline 4 & .32 & .20 & .48 & .01 & .05 & .65 & .09 & .61 & .06 & .50 & .11 & .31 \\
\hline 5 & .36 & .14 & .47 & .02 & .06 & .63 & .06 & .68 & .07 & .56 & .11 & .35 \\
\hline 6 & .36 & .14 & .47 & .03 & .09 & .58 & .03 & .74 & .08 & .59 & .11 & .39 \\
\hline 7 & .35 & .17 & .46 & .04 & .13 & .47 & .01 & .78 & .09 & .59 & .12 & .42 \\
\hline 8 & .33 & .22 & .45 & .05 & .18 & .42 & .00 & .80 & .12 & .56 & .14 & .44 \\
\hline 9 & .30 & .27 & .45 & .07 & .18 & .45 & .02 & .78 & .17 & .51 & .15 & .50 \\
\hline 10 & .27 & .32 & .43 & .09 & .17 & .48 & .06 & .70 & .22 & .46 & .14 & .58 \\
\hline 11 & .27 & .33 & .42 & .13 & .16 & .49 & .13 & .59 & .25 & .44 & .14 & .64 \\
\hline 12 & .30 & .29 & .39 & .19 & .18 & .52 & .20 & .48 & .27 & .43 & .14 & .67 \\
\hline
\end{tabular}

Standard error ranged from 0.00 to .13 for $h^{2}$ and from 0.09 to 0.23 for $\mathrm{P}_{\mathrm{E}}$

$\operatorname{Pr} 1, \operatorname{Pr} 2, \geq \operatorname{Pr} 3$ are the first three parities and more.

Estimates of $\mathrm{P}_{\mathrm{E}_{\mathrm{MK}}}$ (Table 3) were obviously low within the $2^{\text {nd }}$ parity and across the middle of the $1^{\text {st }}$ parity. Contribution of the permanent environmental variation on 
MK across DIM groups were magnified during the later parties where $h^{2}{ }_{\text {MK }}$ estimates were decreasing.

Results of heritability estimates of milking duration $\left(\mathrm{h}^{2}{ }_{\mathrm{DR}}\right)$ within different lactations were mostly near to zero while the corresponding estimates of $\mathrm{P}_{\mathrm{E}_{\mathrm{DR}}}$ were high. Some high values for $\mathrm{h}_{\mathrm{DR}}^{2}$ were obtained slightly during edges of the $1^{\text {st }}$ lactation (from 0.13 to 0.21 and 0.13 to 0.20 ), and during the $2^{\text {nd }}$ half of the $2^{\text {nd }}$ lactation $(0.12$ to 0.27$)$. Milking duration may have an intermediate optimum, because most producers prefer cows with relatively uniform milking duration that do not decrease the flow of cows through the milking parlor. However, selection for extremely short milking duration may be undesirable, because an antagonistic relationship may exist with general udder health (Zhang et al., 1994).

Estimates of $\mathrm{P}_{\mathrm{E}_{\mathrm{DR}}}$ were relatively high reaching $0.80,0.59$, and 0.67 within the $1^{\text {st }}$, $2^{\text {nd }}$ and the later parity, respectively. These results refer to the impact of some environmental conditions which may affect the extent of genetic improvement of this trait across and within all lactations. Meyer and Burnside (1987) concluded that several environmental factors that affect milkability characteristics of individual cows may vary during lactation or between subsequent lactations. Zavadilová et al.(2005) found that variances in milking time of the small permanent environmental effect went up substantially between the first and subsequent lactations, with the differences between the $2^{\text {nd }}$ and the $3^{\text {rd }}$ lactations.

\section{Random regression covariances between and within traits:}

Estimates of additive genetic $\left(\mathrm{R}_{\mathrm{A}}\right)$ and permanent environment correlations $\left(\mathrm{R}_{\mathrm{Pe}}\right)$ between measures of milk yield and milking duration in different months of lactation are illustrated in Figure 1. Estimates of additive genetic correlations for MK decreased in magnitude with increasing interval between measurements. Additive genetic correlations between early and late measures of MK were low and directly changed to negative direction. Therefore, MK in early and late stages of lactation could be considered as different traits. Estimates of additive genetic correlations between measures of DR were around unity across all lactation months. These results may indicate the effectiveness of early selection based on milking duration. On the other hand, $\mathrm{R}_{\mathrm{Pe}_{\mathrm{MK}}}$ appeared to show approximately similar trend to $\mathrm{R}_{\mathrm{A}_{\mathrm{MK}}}$ during most parts of lactation months.

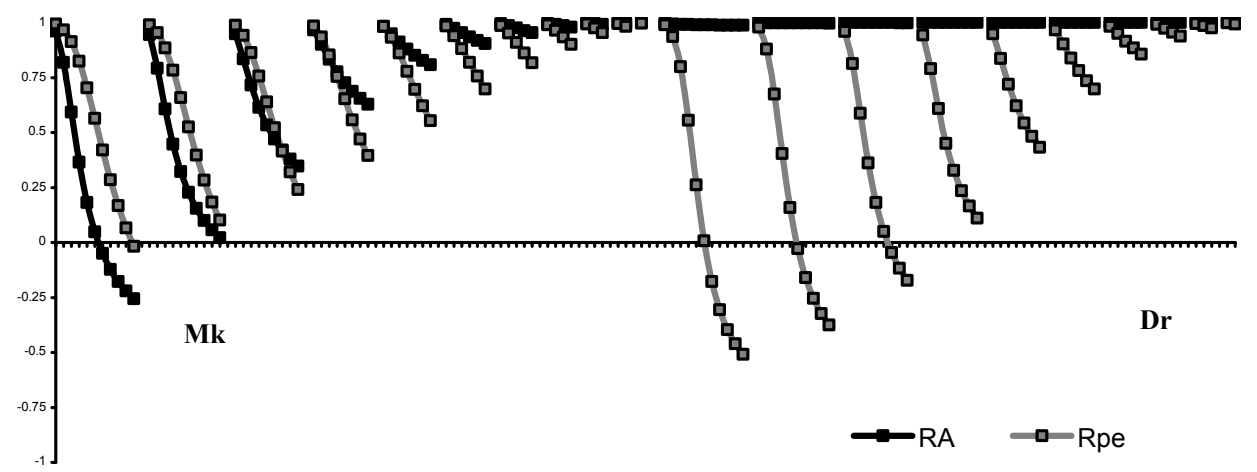

Fig. 1. Estimates of additive genetic $\left(R_{A}\right)$, and permanent environment of $\left(R_{P e}\right)$ correlations within lactation for daily milk yield (MK) and milking duration (DR) across DIM. 
Estimates of additive and permanent environmental correlations between daily milk yield and milking duration using random regression analysis are illustrated in Figure 2. Relationships between milking duration and milk yield were positive across all DIM groups.

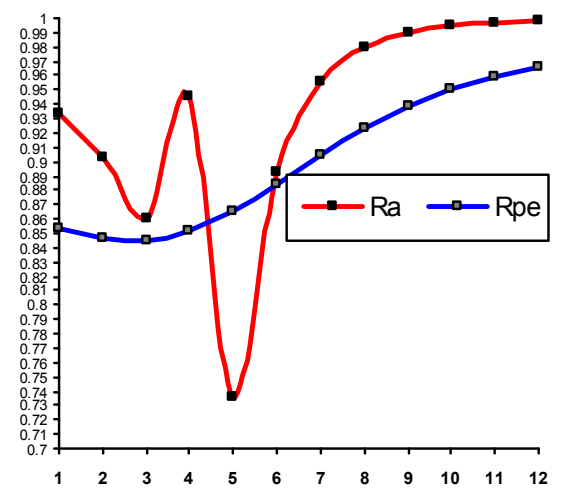

Fig. 2. Estimates of additive genetic and permanent environmental correlations between daily milk yield and milking duration across 12 days in milk groups

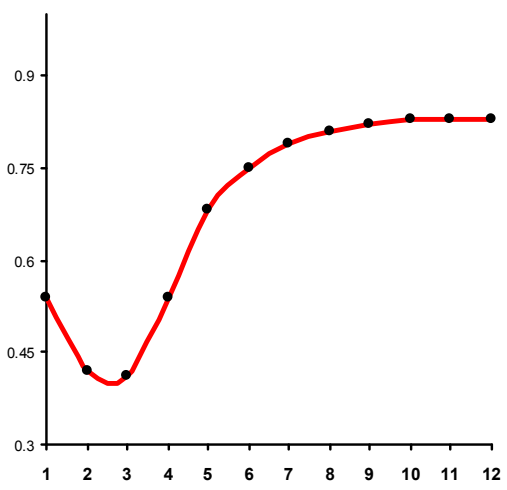

Fig. 3. Estimates of correlations between expected breeding values between daily milk yield and milking duration

Zwald et al. (2005) found that the shape of the milking duration curve tends to be similar to that of a typical lactation curve for milk yield. This is logical because milk letdown of a given cow is expected to be relatively constant across lactation, and milking duration is thus increased when the quantity of milk to be released is greater. In the present study some fluctuation in relationship of MK and DR was obtained during early months of lactation. While changes of the corresponding estimates during the $2^{\text {nd }}$ half of lactation was in flattest shape till the end lactation. In general additive relationship between MK and DR was not less than 0.73 . These results may suggest that high milk production tend to be inheritable along with long milking duration. These results are very important from the economic point of view. Therefore, progressing in genetic improvement of milk production must be restricted with no great prolonging of milking time. This procedure could be save more parlor costs and increase the total net profit of diary farms.

Permanent environmental conditions seem to be important in controlling the relationship between milk yield and milking duration. Estimates of permanent environmental correlations between MK and DR increased linearly with progressing lactation months. Therefore, milking duration may have an intermediate optimum trait in selection programs, because low producer cows that consume long time during milking will disrupt parlor flow and reduce parlor efficiency. On the other hand, high producer cows consuming very short milking time may be at greater risk for mastitis infection.

Estimates of correlations $\mathrm{R}_{\mathrm{BV}}{ }_{\mathrm{DR} * \mathrm{MK}}$ between expected breeding values of milking duration with milk yield are shown in Figure 3. Changes were characterized into two phase, the $1^{\text {st }}$ was in curve shape and ranged from 0.41 to 0.68 (mean $R_{B_{D R} * M K}=$ 
0.52 ) and the $2^{\text {nd }}$ was in flattest shape and ranged from 0.75 to 0.83 (mean $R_{B V} V_{D R} * M K$ $=0.81$ ). It appears that milking durations generally tended to be transmit across generations along with high milk production.

\section{CONCLUSION}

The results show that genetic improvement of both daily milk yield and milking duration is possible and that enhancement of environmental conditions during milking process is the important factor for assessment genetic programs. Milk yield could be considered as different traits along the trajectory especially during early and late of lactation.

\section{ACKNOWLEDGEMENTS}

Appreciations and gratefulness are expressed to the Hungarian Holstein Association for providing milkability and milk production traits of the cows. Gratitude. Thanks are also due to Prof. Gere Tibor for his helpful suggestions and support.

\section{REFERENCES}

Banos, G. and E.B. Bunside, 1992. Genetic evaluation of Canadian dairy bulls for milking speed with an animal model. Can. J. Anim. Sci. 72: 169-172.

Boettcher, P. J., J.C.M. Dekkers, and B. W. Kolstad, 1998. Development of an udder health index for sire selection based on somatic cell score, udder conformation, and milking speed. J. Dairy Sci. 81:1157-1168.

Druet T., F. Javrézic, D. Boichard, and V. Ducrocq, 2003. Modeling lactation curves and estimation of genetic parameters for first lactation test-day records of French Holstein cows. J. Dairy Sci., 86, 2480-2490.

Erf, D. F., L. B. Hansen, and D. A. Lawstuen, 1992. Inheritance and relationships of workability traits and yields for Holsteins. J. Dairy Sci. 75:1999-2007.

Henderson, C. R., Jr. 1982. Analysis of covariance in the mixed model: Higher-level, non-homogeneous, and random regression. Biometrics 38:623-640.

Jakobsen J.H., P. Madsen, J. Jensen, J. Pedersen, L.G. Christensen, and D.A. Sorensen, 2002. Genetic parameters for milk production and persistency for Danish Hol-steins estimated in random regression models using REML. J. Dairy Sci., 85, 1607-1616.

Jamrozik J., and L.R. Schaeffer, 1997. Estimates of genetic parameters for a test day model with random regressions for yield traits of first lactation Holsteins. J. Dairy Sci., 80, 762-770.

Jamrozik J., L.R. Schaeffer, and F. Grignola, 1998. Genetic parameters for production traits and somatic cell score of Canadian Holsteins with multiple trait random regression model. In: Proc. 6th WCGALP, Armidale, 303-306.

Kirkpatrick, M., and N. Heckman, 1989. A quantitative genetic model for growth, shape, reaction norms, and other infinite-dimensional characters. J. Math. Biol. 27:429-450.

Kettunen A., E.A., Mäntysaari and J. Poso, 2000. Estimation of genetic parameters for daily milk yield of primipa-rous Ayrshire cows by random regression test-day models. Livestock Prod. Sci., 66, 251-261. 
Lidauer M., E.A. Mäntysaari, and Stranden I. 2003. Comparison of test-day models for genetic evaluation of production traits in dairy cattle. Livestock Prod. Sci., 79, $73-86$.

Liu Z., F. Reinhardt, and R. Reents, 2000. Estimating parameters of a random regression test day model for first three lactation milk production traits using the covariance function approach. Interbull Bulletin No. 25, 74-80.

Matthew J. V. 2001. Milking parlor management. www.ag.arizona.edu/ extension/ dairy/pdf_files/ MilkingParlorMgmtrevised.pdf Oct 2001

Meyer, K., and E. B. Burnside, 1987. Scope of a subjective assessment of milking speed. J. Dairy Sci. 70:1061-1068.

Meyer, K., and W. G. Hill, 1997. Estimation of genetic and phenotypic covariance functions for longitudinal or 'repeated' records by restricted maximum likelihood. Livest. Prod. Sci. 47:185-200.

Meyer, K., 1998. " $\mathrm{D}_{\mathrm{X}} \mathrm{M}_{\mathrm{RR}}$ " a program to estimate covariance functions for longitudinal data by restricted maximum likelihood in proceeding $6^{\text {th }}$ WCGA 1216 Jan. University New England, Armidale, 27: 465-466.

Moore, R. K., B. W. Kennedy, E. B. Burnside, and J. E. Moxley, 1983. Relationships between speed of milking and somatic cell count and production in Holsteins. Can. J. Anim. Sci. 63:781-789.

Pool M.H., and T.H.E. Meuwissen, 2000. Reduction of the number of parameters needed for a polynomial random regression test day model, Livestock Prod. Sci., 64, 133-145.

Olori V.E., W.G . Hill, Mc. Guirk and B.J. Brotherstone, 1999. Estimating variance components for test day milk records by restricted maximum likelihood with random regression animal model. Livestock Prod. Sci., 61, 53-63.

Rekaya R., M.J. Carabaño, and M.A.Toro, 1999. Use of test day yields for the genetic evaluation of production traits in Holstein-Friesian cattle. Livestock Prod. Sci., 57, 203-217.

Schaeffer, L. R., and J. C. M. Dekkers, 1994. Random regression in animal models for test-day production in dairy cattle. Proc. 5th World Cong. Genet. Appl. Livest. Prod., Guelph, Canada 18:443-446.

Strabel T., and I Misztal, 1999. Genetic parameters for first and second lactation milk yields of Polish Black and White cattle with random regression test-day models. J. Dairy Sci., 82, 2805-2810.

Swalve H.H., 1995. Test day models in the analysis of dairy production data - a review. Arch. Tierzucht, 38, 591-612.

Van der Werf, J. H. J., M. E. Goddard, and K. Meyer, 1998. The use of covariance functions and random regression for genetic evaluation of milk production. J. Dairy Sci. 81:3300-3308.

Zavadilová, L.; J. Jamrozik, L.R. Schaeffer, 2005. Genetic parameters for test-day model with random regressions for production traits of Czech Holstein cattle. Czech J. Anim. Sci., 50: 142-154

Zhang, W. C., J. C. M. Dekkers, G. Banos, and E. B. Burnside. 1994. Adjustment factors and genetic evaluation for somatic cell score and relationships with other traits of Canadian Holsteins. J. Dairy Sci. 77:659-665.

Zwald, N. R., K. A. Weigel, Y. M. Chang, R. D. Welper and J. S. Clay, 2005. Genetic evaluation of dairy sires for milking duration using electronically recorded milking times of their daughters. J. Dairy Sci. 88:1192-1198. 
نموذج الحيوان للإعتماد العشوائى للتقيم الوراثى لإختبار إنتاج اللبن اليومى والوقت المستغرق فى الحليب فى الهولستين فيرزيان

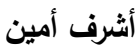

\section{جامعة قناة السويس، كلية الزراعة، قسم الانتاج الحيوانى، ب ro اء الاسماعيلية - مصر}

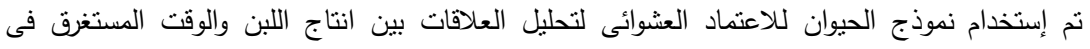

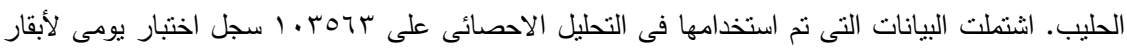

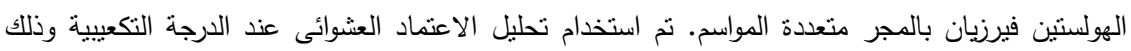

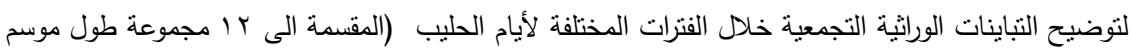

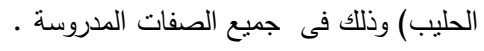

وقد اظهرت نتائج تحليل البيانات الكلية المشتملة على مجاميع المواسم الانتاجية أن هناك تطوراً وراثياً

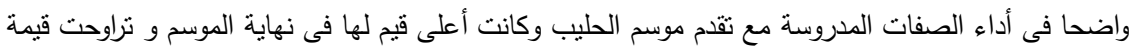

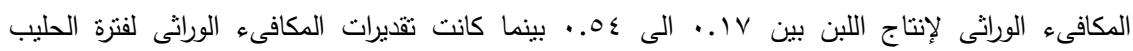

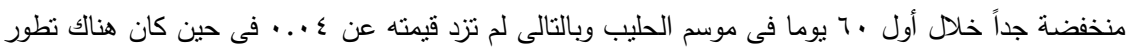

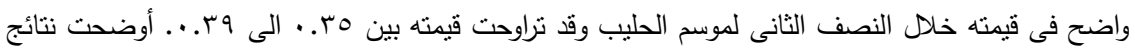

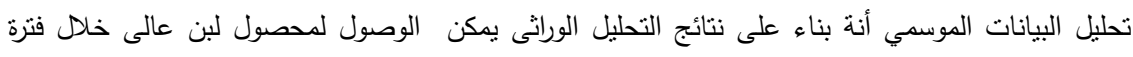

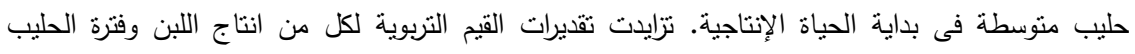

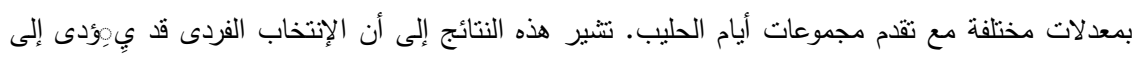

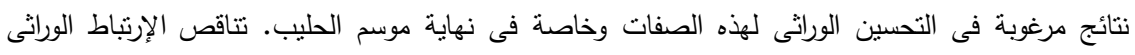

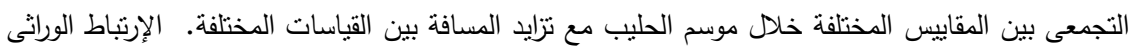

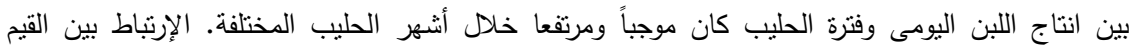

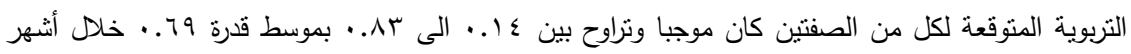
الحليب المختلفة. ويحتوى متن البحث على نتائج أكثر تفصيلا عن القيم التربوية والارتباطات الوراثية والئئية

$$
\text { الدائمة لجميع الصفات المدروسة. }
$$

